\title{
THE EFFECTS OF BREED, SIRE AND ENVIRONMENTAL FACTORS ON THE BIRTH AND WEANING WEIGHT OF LAMBS
}

\author{
S. Kramarenko, DSc in Biology \\ ORCID ID: 0000-0001-5658-1244
}

A. Kramarenko, $\mathrm{PhD}$ in Agriculture

ORCID ID: 0000-0002-2635-526X

S. Lugovoy, DSc in Agriculture

ORCID ID: 0000-0001-6505-8105

Mykolayiv National Agrarian University, Ukraine

D. Balan, $\mathrm{PhD}$ in Biology

ORCID ID: 0000-0002-1014-1275

State Agrarian University of Moldova, Moldova

K. Zemoglyadchuk, PhD in Biology

ORCID ID: 0000-0001-6380-5349

Belarusian State Pedagogical University named after Maxim Tank, Belarus

The aim of this study was to determine the effect of some important factors influencing on the birth and weaning weight variability in lambs. Data from 2603 ewes was included in the analysis, where 3961 lambs were obtained during the five years of the research. Data was tested using analysis of variance (ANOVA) with the GLM procedure of Minitab Release 13.1. Our results presented significant influence on the year of lambing, breed, ram genotype, age of a dam, type of a birth (litter size), sex of a lamb and on the birth weight and weaning weight of lambs.

Keywords: birth and weaning weight of lambs; ram genotype; year of lambing; age of ewes; litter size (type of birth); sex of a lamb; the Ascanian fine-fleece breed.

Relevance. Sheep in the domain of developing countries adapt well to severe climatic conditions and arduous terrains that are often not suitable for raising the larger livestock and are fully exploited for their ability to produce a variety of commodities without disrupting the cultural harmony. Today, as many as 418 sheep breeds that have been documented in nearly 75 countries are combinations of two or more distinct breeds, populations and landraces [1]. Phenotypic radiation under selection is ongoing, resulting in a spectrum of modern breeds adapted to a diverse range of environments and exhibiting the specialised production of meat, milk, and fine wool. The last few hundred years has seen the pace of genetic gain increase dramatically through the division of animals into breeds, the implementation of quantitative genetics methodology, and the use of artificial insemination to prioritise genetically superior rams [2]. Various authors have studied the influence of maternal effects in relation to their economic importance in domestic mammals and from the theoretical academic interest and dam breed effects were significant and considerable on weaning weight [3].
Sheep production is affected by genetic and nongenetic factors. The knowledge of these factors is essential for efficient management and for the accurate estimation of breeding values [4]. Lamb weight and daily gaining are important components influencing the profitability of sheep and are two important objectives in selection strategies. Growth in weight reflects the genes an animal has inherited from its parents (direct additive effects), and a mix of seasonal and husbandry factors peculiar to a production system or farm. As a part of the phenotypic variance of the growth traits is heritable, genetic improvement in these traits through selection programmes would be possible [5].

In Vesely \& Peters [6] it has been shown that some environmental factors favored the later-bearing ewes. Climate and seasonal differences among different years affect the production of the whole flock, while sex, type of birth, age and weight affect the individual growth performance. Birth size/weight represents the greatest initial barrier on weaning and pre-weaning growth among the non-genetic factors in sheep. Birth weight, weaning weight and efficiency of pre- and post-weaning gains are growth traits of economic

(C) Kramarenko S., Kramarenko A., Lugovoy S. та ін., 2020 
importance with regards to the cost and efficiency of meat production in sheep. Therefore, understanding of the extent of influence of both genetics and environmental factors becomes very important for devising efficient and effective management plans in sheep [3].

Adjustment of performance records for nongenetic effects is also necessary in genetic evaluation schemes. Birth and weaning weights of lambs were usually influenced by physiological, environmental and genetic effects. Environmental effects include the age of ewe, litter size, growth type and lamb sex. Growth curve analysis in many species clearly indicates direct relation between birth weight, weaning weight and daily growth [7].

Analysis of recent research. As it was shown earlier, the year of lambing was one of the major sources of variations in weaning weight, and effects of litter size (single or twin) on birth weight and weaning weight were significant in the Rambouillet, Romnelet, Canadian Corriedale, and Romeldale sheep [6]. In addition, age of dam had significant effects on birth weight and weaning weight but was relatively unimportant as a source of variation. Analysis of the lambs from the Hampshire, Columbia-Southdale, Targhee, Suffolk and Dorset breeds of sheep and all possible crosses among these breeds have been shown that years of lambing, age of a dam, type of birth, sex of a lamb and breed groups all these had significant effects on the studied traits (birth weight, weaning weight, gain from birth to weaning and average daily gain) [8].

In the Navajo and Navajo cross-bred sheep, year of lambing, breeding-group, age of a dam, type of birth (litter size), sex of a lamb and lamb's birth weight affected significantly all weaning traits [9]. Male lambs of the Baluchi sheep in comparison with female lambs and single-born lambs in comparison with multiple-born lambs had higher birth weight and daily growth, however, effect of a litter size on birth and weaning weights was higher in young ewes [7]. The effect of herd, sex of lambs, dam age and birth year on all traits (birth weight, weaning weight and body weight at 6 months) and birth type in the Lori sheep had significant effect only on weaning weight [10]. Single-born crossbred (the Dorper $\times$ indigenous sheep breeds) lambs had higher weight at birth, weaning weight, and pre-weaning average daily gain as compared to twins. Sex of a lamb, in comparison, was significant and male lambs recorded highest preweaning growth performance compared to female counterparts. Parity, season, and year of lambing significantly influenced the pre-weaning growth of crossbred lambs [11].

A similar report was given by Sánchez-Dávila et al. [12] who also proved that environmental conditions are important source of variation in a litter size, birth, and weaning weight in sheep under semiarid climate. The lambing breeding season had a significant effect on weaning weight in the Saint Croix hair sheep - the highest weaning weights were recorded in lambs born in spring and the lowest ones in those which were born in summer. A lambing year had a significant effect on a litter size and weaning weight, since the values of both traits improved through the years.

Different non-genetic factors such as year, sex, type of birth and dam's age had a significant influence on birth weight and weaning weight of lambs (see the review in [3]). Season of lambing influenced the birth weight while it had no significant effect on weaning weight in the Bharat Merino lambs. The trend of the increase in birth weight and weaning weight of the lambs is being observed up to the period when the age of their corresponding dams is $4-5$ years. Thus, the findings of the study [13] showed that non-genetic factors play an important role in the expression of genetic potential in the lambs as well as growth performance of the Bharat Merino sheep under sub temperate conditions.

Sheep breeding in Ukraine historically has always been an integral part of the national economy, which meets its needs for specific types of raw materials and food [14]. But the high cost of production remains the main problem of sheep breeding. Despite the fact that the cost of fodder, energy appliances, and ways of mechanization in Ukraine has reached the world level, but the prices for this kind of products, dictated by the modern market, are only $30-40 \%$ of world prices [15]. In Ukraine, sheep breeding is represented by the largest number of breeds and breed types, although this species is characterized by a significant reduction in the number of ewes, and it was mostly noticeable during 2011-2019 [16]. Successful sheep breeding requires a perfect breeding programme, which should take into account the influence of various factors at all stages of the technological process. At the same time the birth and weaning weight in lambs has a major role in achieving profitable in the sheep breeds raised for meat and wool $[17 ; 18]$.

The aim of this study was to determine the effect of some important factors (genetic and non-genetic nature) influencing the birth and weaning weight variability in lambs.

Materials and methods of research. The study was carried out on the basis of the Institute of Animal Husbandry of Steppe Regions named by M. F. Ivanov "Askania-Nova" - the National Scientific Agricultural Center in Sheep Breeding of NAAS. The object of the study was the influence of genetic and non-genetic factors on the birth and weaning weight 
of lambs. Data from 2603 ewes was included in the analysis, where 3961 lambs were obtained during the five years of the research.

The reproductive qualities of the Ascanian finefleece ewes (AC) were evaluated by their matching with the sires of the following genotypes which are the Ascanian fine-fleece, the Australian merino (AM) and the half-bred rams $(1 / 2 \mathrm{AC}+1 / 2 \mathrm{AM})$. The influence of the year of lambing, age of ewes, litter size, sex of lambs on weight of lambs at birth and weaning was also studied.

Two models were used for data on the birth and weaning weight of lambs:

$$
\begin{array}{ll}
\mathrm{WB}_{\mathrm{ijklmn}}=\mu+\mathrm{YEAR}_{\mathrm{i}}+\mathrm{Sire}_{\mathrm{j}}+\mathrm{AGE}_{\mathrm{k}}+\mathrm{LS}_{\mathrm{l}}+ \\
\mathrm{SEX}_{\mathrm{m}}+\mathrm{e}_{\mathrm{ijklmn}} ; & (\text { Model 1) } \\
\mathrm{WW}_{\mathrm{ijklmn}}=\mu+\mathrm{YEAR}_{\mathrm{i}}+\mathrm{Sire}_{\mathrm{j}}+\mathrm{AGE}_{\mathrm{k}}+\mathrm{LS}_{1}+ \\
\mathrm{SEX}_{\mathrm{m}}+\mathrm{e}_{\mathrm{ijklmn}} ; & (\text { Model 2) }
\end{array}
$$

where: $\mathrm{WB}$ - the individual birth weight of a lamb; WW - the individual weaning weight of a lamb; $\mu$ the population mean; $Y_{E A R}$ - the fixed effect of $i$-th year of lambing $(i=1 \ldots 5)$; Sire $_{j}-$ the fixed effect of $\mathrm{j}$-th a ram genotype $(\mathrm{j}=1 \ldots 3) ; \mathrm{AGE}_{\mathrm{k}}-$ the fixed effect of $\mathrm{k}$-th age of a dam $(\mathrm{k}=1 \ldots 8) ; \mathrm{LS}_{1}-$ the fixed effect of 1-th size of a litter $(1=1 \ldots 3)$; $\mathrm{SEX}_{\mathrm{m}}-$ the fixed effect of $m$-th sex of a lamb $(m=1 \ldots 2) ; e_{i j k l m n}$ - the residual effect.

A significance level of 0.05 was used for all analyses. Data was tested using analysis of variance (ANOVA) with the GLM procedure of Minitab Release 13.1 [19].

Results. The significant effect on the weight of lambs at birth and weaning was established for all factors which were used in the analysis. The significant influence of the ram genotype on the birth weight of lambs was not established (Table 1).

In general, the population means $(\mu)$ were $4.047 \pm$ 0.035 and $26.83 \pm 0.38 \mathrm{~kg}$ for birth and weaning weight of lambs, respectively.

Least squares estimates of deviations from the population mean and standard errors (LSE \pm SE) shown by subclasses for the year of lambing are presented in Table 2 .

Table 1

Summary of Analysis of Variance for each of two traits

\begin{tabular}{|l|c|c|c|c|}
\hline \multirow{2}{*}{ Source of variation } & \multicolumn{2}{|c|}{ Birth weight of a lamb (Model 1) } & Weaning weight of a lamb (Model 2) \\
\cline { 2 - 5 } & $F$ & $p$ & $F$ & $p$ \\
\hline Year of lambing & 205.67 & $<0.001$ & 91.44 & $<0.001$ \\
\hline Ram genotype & 2.51 & $\mathrm{~ns}$ & 9.00 & $<0.001$ \\
\hline Age of a dam & 4.45 & $<0.001$ & 2.99 & 0.004 \\
\hline Litter size & 404.19 & $<0.001$ & 68.89 & $<0.001$ \\
\hline Sex of a lamb & 46.61 & $<0.001$ & 34.60 & $<0.001$ \\
\hline
\end{tabular}

Table 2

Least squares estimates of deviations from the population mean and standard errors (LSE \pm SE) shown by subclasses for the year of lambing, $\mathrm{kg}$

\begin{tabular}{|c|c|c|}
\hline Subclass & Birth weight of a lamb (Model 1) & Weaning weight of a lamb (Model 2) \\
\hline Constant & $4.047 \pm 0.035^{* * *}$ & $26.83 \pm 0.38^{* * *}$ \\
\hline $1^{\text {st }}$ & $0.038 \pm 0.021$ & $-1.64 \pm 0.23^{* * *}$ \\
\hline $2^{\text {d }}$ & $0.377 \pm 0.018^{* * *}$ & $3.21 \pm 0.20^{* * *}$ \\
\hline $3^{\text {d }}$ & $-0.484 \pm 0.020^{* * *}$ & $-1.03 \pm 0.22^{* * *}$ \\
\hline $4^{\text {th }}$ & $0.048 \pm 0.024^{*}$ & $1.15 \pm 0.26^{* * *}$ \\
\hline $5^{\text {th }}$ & 0 & 0 \\
\hline
\end{tabular}

Notes: $*-p<0.05 ; * *-p<0.01 ; * * *-p<0,001$.

The birth weight of lambs significantly exceeded the population mean among ewes which lambed during the 2 nd $(+377 \mathrm{~g})$ and 4 th $(+48 \mathrm{~g})$ years of lambing, while ewes which lambed during the 3rd year, gave birth to lambs which were lighter than the population mean for $484 \mathrm{~g}$.

Lambs, which were born during the 1st and 3rd years of lambing, were significantly lower than the population mean (for 1.64 and $1.03 \mathrm{~kg}$, respectively). In contrast, ewes which lambed during the 2 nd and 4th years of lambing, on the other hand, gave birth to lambs which significantly exceeded the population mean (by 3.21 and $1.15 \mathrm{~kg}$, respectively). In general, the periods of increase or decrease coincided for the birth/weaning weight of lambs (Table 2).

Least squares estimates of deviations from the population mean and standard errors (LSE $\pm \mathrm{SE}$ ) shown by subclasses for the ram genotype are presented in Table 3. 
Table 3

Least squares estimates of deviations from the population mean and standard errors (LSE \pm SE) are shown by subclasses for the ram genotype, $\mathrm{kg}$

\begin{tabular}{|l|c|c|}
\hline \multicolumn{1}{|c|}{ Subclass } & Birth weight of a lamb (Model 1) & Weaning weight of a lamb (Model 2) \\
\hline Constant & $4.047 \pm 0.035^{* * *}$ & $26.83 \pm 0.38^{* * *}$ \\
\hline AM & $-0.033 \pm 0.018$ & $-0.78 \pm 0.20^{* * *}$ \\
\hline $1 / 2 \mathrm{AC}+1 / 2 \mathrm{AM}$ & $-0.031 \pm 0.018$ & $0.01 \pm 0.20$ \\
\hline $\mathrm{AC}$ & 0 & 0 \\
\hline
\end{tabular}

As it was shown above (Table 1), the birth weight of lambs did not depend on the genotype of the ram. According to the weaning weight of lambs the ewes, which were mated with the AM rams, gave birth to lambs, which were inferior to the population mean by $0.78 \mathrm{~kg}$ (Table 3).
Least squares estimates of deviations from the population mean and standard errors (LSE $\pm \mathrm{SE}$ ) shown by subclasses for the age of a dam and presented in Table 4.

Table 4

Least squares estimates of deviations from the population mean and standard errors (LSE \pm SE) are shown by subclasses for the age of a dam, $\mathrm{kg}$

\begin{tabular}{|c|c|c|}
\hline Subclass & Birth weight of a lamb (Model 1) & Weaning weight of a lamb (Model 2) \\
\hline Constant & $4.047 \pm 0.035^{* * *}$ & $26.83 \pm 0.38^{* * *}$ \\
\hline 2 & $-0.155 \pm 0.035^{* * *}$ & $-0.32 \pm 0.38$ \\
\hline 3 & $-0.002 \pm 0.026$ & $0.17 \pm 0.29$ \\
\hline 4 & $0.009 \pm 0.027$ & $0.51 \pm 0.30$ \\
\hline 5 & $0.049 \pm 0.029$ & $1.06 \pm 0.32^{* * *}$ \\
\hline 6 & $0.010 \pm 0.031$ & $0.85 \pm 0.34^{*}$ \\
\hline 7 & $0.028 \pm 0.035$ & $-0.29 \pm 0.39$ \\
\hline 8 & $0.101 \pm 0.051^{*}$ & $-0.02 \pm 0.56$ \\
\hline 9 & 0 & 0 \\
\hline
\end{tabular}

The birth weight of lambs was significantly higher than the population mean among eight years old ewes (101 g), while the youngest ewes, by the contrast, gave birth to lambs which were significantly lower than the population mean (by $155 \mathrm{~g}$ ). As for the weaning weight of lambs, middleaged ewes (5-6 years old) gave birth to lambs which significantly exceeded the population mean by 0.85 $1.06 \mathrm{~kg}$ (Table 4).

Least squares estimates of deviations from the population mean and standard errors (LSE $\pm \mathrm{SE}$ ) shown by subclasses for the litter size are presented in Table 5 .

Table 5

\section{Least squares estimates of deviations from the population mean and standard errors (LSE $\pm \mathrm{SE}$ )} shown by subclasses for the litter size, $\mathrm{kg}$

\begin{tabular}{|c|c|c|}
\hline Subclass & Birth weight of a lamb (Model 1) & Weaning weight of a lamb (Model 2) \\
\hline Constant & $4.047 \pm 0.035^{* * *}$ & $26.83 \pm 0.38^{* * *}$ \\
\hline 1 & $0.561 \pm 0.030^{* * *}$ & $1.89 \pm 0.31^{* * *}$ \\
\hline 2 & $0.011 \pm 0.029$ & $-0.71 \pm 0.31^{*}$ \\
\hline 3 & 0 & 0 \\
\hline
\end{tabular}

As it was expected, the weight of singles was significantly higher than the population mean at birth $(561 \mathrm{~g})$ and at weaning $(1.89 \mathrm{~kg})$. The weaning weight was significantly lower by $0.71 \mathrm{~kg}$ for ewes lambing twins (Table 5).
Least squares estimates of deviations from the population mean and standard errors (LSE \pm SE) shown by subclasses for the sex of a lamb are presented in Table 6 . 
Table 6

Least squares estimates of deviations from the population mean and standard errors ( $L S E \pm S E$ ) shown by subclasses for the sex of lamb, kg

\begin{tabular}{|l|c|c|}
\hline \multicolumn{1}{|c|}{ Subclass } & Birth weight of a lamb (Model 1) & Weaning weight of a lamb (Model 2) \\
\hline Constant & $4.047 \pm 0.035^{* * *}$ & $26.83 \pm 0.38^{* * *}$ \\
\hline male lambs & $0.074 \pm 0.010^{* * *}$ & $0.66 \pm 0.11^{* * *}$ \\
\hline female lambs & 0 & 0 \\
\hline
\end{tabular}

The ram lambs significantly exceeded the ewe lambs by $74 \mathrm{~g}$ at birth and by $0.66 \mathrm{~kg}$ at weaning (Table 6).

Least squares estimates of deviations from the population mean shown by subclasses for a ram number are presented in Figure 1. In general, ewes mated to rams №№ 519 and 748, gave birth to lambs which significantly exceeded the population mean, whereas ewes mated to a ram № 6640, on the contrary, gave birth to lambs which were significantly lower the population mean for the birth weight of lambs (Fig. 1A).

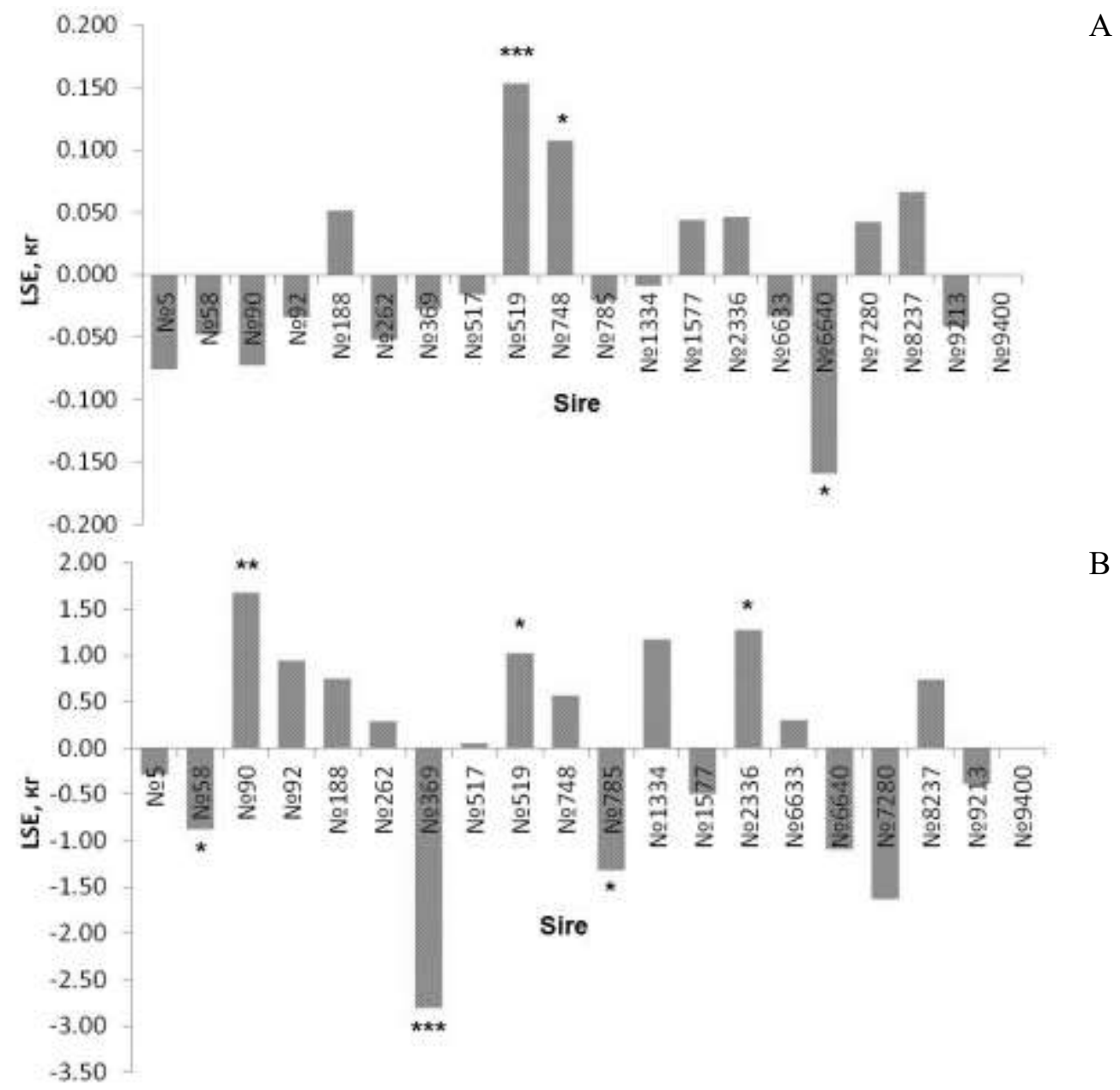

Figure 1 - Least squares estimates of deviations from the population mean and standard errors (LSE \pm SE) shown by subclasses for a ram number: A - Birth weight of a lamb; B - Weaning weight of a lamb $\left(^{*}-p<\right.$ 0.05 ; $\left.^{* *}-\mathrm{p}<0.01 ; * * *-\mathrm{p}<0.001\right)$

In relation to the weaning weight of lambs, ewes mated to rams №№ 90, 519 and 2336, gave birth to lambs which significantly exceeded the population mean, while ewes mated to rams №№ 58, 369 and 785 , on the contrary, gave birth to lambs, which were significantly lower the population mean for the weaning weight (Fig. 1B).
Thus, only for a ram № 519 it is possible to state high prepotency according to the potential of increasing the weight of lambs both at birth and at weaning. In total, for 20 sires, a significantly relationship between their LS-estimates of birth and weaning weight of lambs was not established $(\mathrm{r}=$ 0.293; $n=20 ; p=0.209$ ) (Fig. 2). 


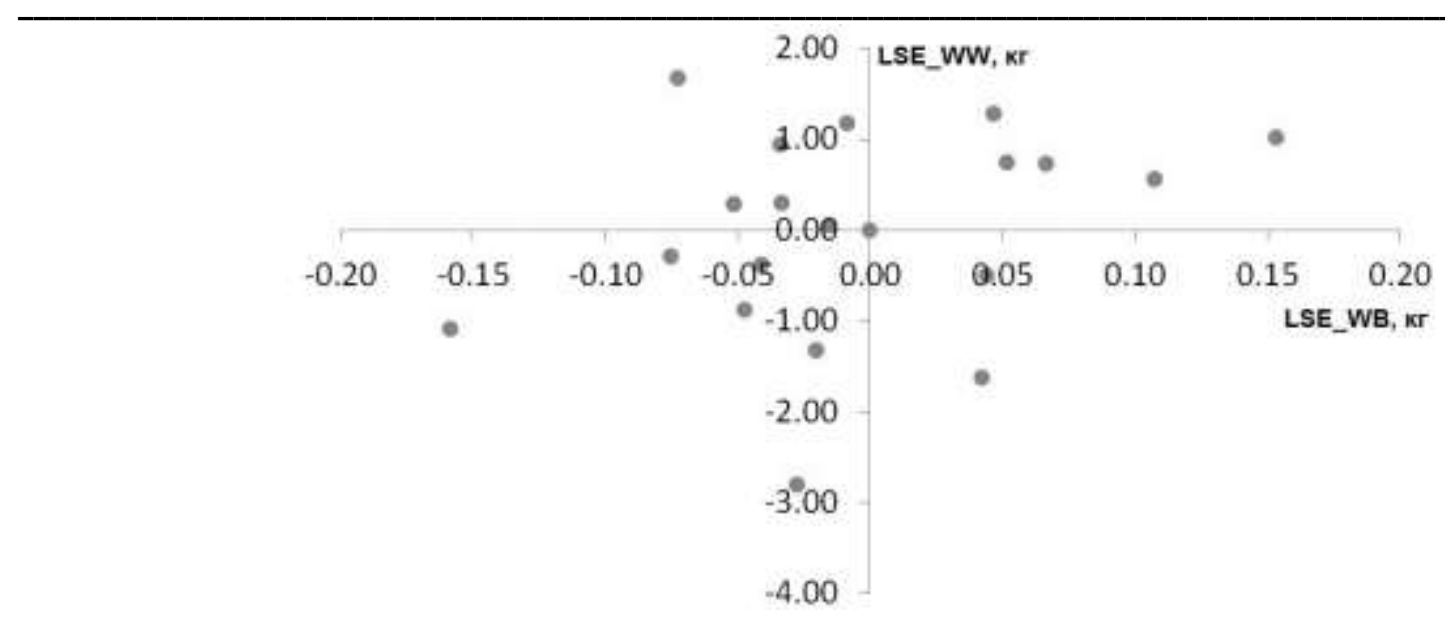

Figure 2 - Scatter-plot of sires based on the Least squares estimates of deviations from the population mean for the birth weight (LSE_WB) and weaning weight of a lamb (LSE_WW)

Discussion. Birth weight of lambs. Our results presented a significant influence of the lambing year, breed, sire genotype, age of a dam, type of a birth (litter size) and sex of a lamb on the birth weight and weaning weight of lambs which is in a good agreement with the results obtained by other authors. This was in the agreement with observations by Assan \& Makuza [4] that year of lambing had significant effect $(\mathrm{p}<0.05)$ on birth weight in indigenous the Sabi, the Mutton Merino and the Dorper sheep.

A number of studies reported about influence of the birth type on lamb performance, to which singletons outclassed the twin birth (see the review in [3]). Type of a birth was the largest source of variation in birth weight of the Rambouillet, Romnelet, Canadian Corriedale, and Romeldale lambs [6]. The effect of birth status was nonsignificant in the Dorper and Mutton Merino sheep while effect of birth status was significant on birth weight in indigenous the Sabi sheep [4]. In 60\% of the dead lambs in the Romney and cross Border Leicester $\times$ Romney sheep, $44.6 \%$ of single-born lambs died of dystokia and $15.1 \%$ from physiological starvation. Of the multiple-born lambs autopsied, $16 \%$ died from dystokia and $41.7 \%$ from starvation. Most of the deaths occurred within 3 days of birth, and relatively more single- than multipleborn lambs died at birth [20].

Lambs born to first-parity ewes were lighter ( $\mathrm{p}<$ $0.01)$ at birth than lambs of older ewes. Parity did not have any significant effects on pre-weaning growth rate [21]. Two-year-old ewes of the Rambouillet, Romnelet, Canadian Corriedale, and Romeldale sheep bore lighter lambs than the older ewes. The birth weights showed a slight increase for each year of increase in the age of dams up to 6 years of age [6]. The age of a dam exerts most of its influence on pre-weaning traits in the Navajo and Navajo cross-bred sheep. Dams $8+$ years of age had lambs that were heavier at birth than all other groups. However, their lambs were lighter at weaning than those from 4 to 7 years of age. This could be due to better intra-uterine environment, while not providing as much milk. This pointed to the fact that selection pressure exerted on older ewes might be more intense, causing those surviving to give heavier lambs at birth [9]. On the other hand, in the Romney and cross Border Leicester $\times$ Romney sheep lamb survival rate (lambs weaned as a percentage of all lambs born) increased with increasing age of dams for both single- and multipleborn lambs [20].

Morris et al. [22] reported that analyses of variance for perinatal survival and pre-weaning survival in the lambs on the New Zealand research stations showed the significant effects of contemporary group of lamb, the age of a dam, and the birth rank-sex combinations, whilst linear and curvilinear effects of birth weight were also significant. Optimal birth weights of lambs were $4.36 \mathrm{~kg}$ and $4.77 \mathrm{~kg}$ for maximal perinatal survival and maximal pre-weaning survival, respectively. At the same time, these authors noted that heavy singles and twins were at higher risk of not surviving, but light singles and twins were also at risk. At birth, survival was consistently lowest from lambs out of 2-year-old dams, whilst pre-weaning survival was lower amongst lambs from 2- and 5-year-old dams, and higher in lambs from 3- and 4-year-old dams.

Sire had significant effects $(p<0.05)$ on birth weight in the Mutton Merino and indigenous the Sabi sheep in Zimbabwe [4]. Sánchez-Dávila et al. [12] demonstrated that effect of ram in the Saint Croix hair sheep was significant for each of the traits considered: there were differences up to one lamb per litter, also differences up to $1.5 \mathrm{~kg}$ for birth weight and up to $6.5 \mathrm{~kg}$ for weaning weight among rams.

According to Eltawil et al. [9], a sex of a lamb 
was responsible for $1.6,3.5$ and $27.9 \%$ of total variability in birth, weaning and yearling body weights, respectively. Such a trend in the effect of a sex on body weights might be attributable to different physiological functions in the two sexes, mainly of a hormonal nature that tend to become more pronounced as animals approach maturity.

Mortality in lambs of different breeds was 1 to $5 \%$ higher for males than for females. At the same litter size and ratio of birth weight to a mature size, the more prolific breeds were superior in lamb viability and had lower optimum birth weights. The age of dams, litter sizes, and birth weights all had important, often quadratic, effects on lamb's mortality that differ among breeds [23].

Analysis of variance of birth weight in the Romney and cross Border Leicester $\times$ Romney sheep showed that male lambs were 0.5 pounds (227 g) heavier than females and singles 2.3 pounds (1043 g) heavier than twins. Lamb birth weight increased from two-year-old to five-year-old dams [20]. GLM analysis in our study showed that male lambs were only $74 \mathrm{~g}$ heavier than females and singles were $561 \mathrm{~g}$ heavier than twins (Tables 5 and $6)$.

Weaning weight of lambs. In our study year of lambing differences of the weaning weight of lambs were significant is consistent with the results in the Rambouillet, Romnelet, Canadian Corriedale, and Romeldale sheep [6]. In our study single lambs were $2.60 \mathrm{~kg}$ heavier than twins. These results are very similar to those in other studies. At weaning single lambs were 12.5 pounds $(5.67 \mathrm{~kg})$ heavier than twins lambs in the Romnelet sheep [24], thus in Hazel \& Terrill [25] the Rambouillet singles were 9.2 pounds $(4.14 \mathrm{~kg})$ heavier than twins. Similarly, Hazel \& Terrill [26] reported on the effects of environmental factors on weaning weight in pooled data for the Columbia, Corriedale and Targhee lambs. Their results showed that singles were 11.7 pounds (5.31 $\mathrm{kg}$ ) heavier than twins. Thus, the differences between singles and twins were statistically significant, but a part of this difference might be due to the heavier weight of singles at birth [9].

Ploumi and Emmanouilidis [27] reported that month of lambing influenced a litter size, a lamb birth and a weaning weight in the Serrai ewes. There was also a significant effect of a litter size on a lamb weight at birth and weaning. In our study lambs raised by mature (5 to 6-year-old) dams were 0.85 $1.06 \mathrm{~kg}$ heavier than those raised by 2-year-old ewes (Table 4). In a similar study [6], lambs from mature ewes were 1.8 to 3.0 pounds $(0.82-1.36 \mathrm{~kg})$ heavier than lambs from 2-year-old ewes. There were no significant differences in weaning weight of lambs from the different age classes of mature ewes. There was, however, a slight decline in weaning weight after the ewes reached 6 years of age. This was partly in agreement with Vesely \& Slen [24], who demonstrated that at weaning lambs raised by mature dams of the Romnelet sheep were 2.7 pounds $(1.22 \mathrm{~kg})$ heavier than those raised by 2 -year-old ewes, thus in Hazel \& Terrill [25] the Rambouillet lambs raised by mature dams were 6.1 pounds $(2.77$ $\mathrm{kg}$ ) heavier than those raised by 2 -year-old dams. In another report Hazel \& Terrill [26] reported than lambs of the Columbia, Corriedale and Targhee sheep raised by mature dams were 8.7 pounds ( 3.95 $\mathrm{kg}$ ) heavier than those raised by 2 -year-old dams.

Bathaei \& Leroy [28] reported that the sex of a lamb of the Mehraban breed had the most important influence on the pre-weaning traits $(p<0.001)$. The male lambs were significantly heavier than the female lambs at weaning $(1.71 \mathrm{~kg})$ and had a significantly higher rate of growth from birth to weaning ( $22 \mathrm{~g} /$ day). Male lambs of the Norduz breed were heavier $(\mathrm{p}<0.01)$ than female lambs at weaning and 180 days of age by 1.0 and $2.3 \mathrm{~kg}$, respectively [29]. In our study significant difference in body weight due to the sex of a lamb was only recognized in weaning weight of lambs - male were heavier than female lambs by $0.66 \mathrm{~kg}$ (Table 6 ). Sex difference could be explained by the influence of sexual hormones on animal development affecting body dimensions and fat deposits, as well as, muscle and bone tissues [30].

Assan \& Makuza [4] observed that sires had significant effects $(\mathrm{p}<0.05)$ on birth weight in the Mutton Merino and the indigenous Sabi sheep in Zimbabwe. Increases in body weight due to crossbreeding (hybrid vigor) were more evident in weaning weight and gain from birth to weaning than in birth weight in the Hampshire, ColumbiaSouthdale, Targhee, Suffolk and Dorset breeds of sheep and on all possible crosses [8]. On the other hand, Alsheikh [31] reported that the level of inbreeding in the Barki lambs had a negative significant effect on birth weight while it had no significant effect on weaning weight. In our study significant difference in body weight due to ram genotype was only recognized in weaning weight of lambs (Tables 1 and 3).

This implies that lambs that have heavier birth weights that might be due to being males, singles and/or from mature ewes, tend to achieve higher weights at weaning, partly because of the close relationship between both traits [9]. On the other hand, lamb survival rate was also related to birth weight. In single-born lambs survival rate was highest in lambs of about average birth weight and decreased with lambs of lower or higher birth weights. In multipleborn lambs survival rate was lowest with lambs of low birth weight and increased with increasing birth weight [20]. 
Conclusions and prospects of use. The significant effect on the weight of lambs at birth and weaning was established for all factors which were used in the analysis. The significant influence of the ram genotype on the birth weight of lambs was not established. Only for a ram № 519 it is possible to state high prepotency according to the potential of increasing the weight of lambs both at birth and at weaning. In total, for 20 sires, a significantly relationship between their LS-estimates of birth and weaning weight of lambs was not established $(r=$ $0.293 ; n=20 ; p=0.209$ ).

Acknowledgements. Our research was financially supported by the Ministry of Education and Science of Ukraine (State Registration Number 0119U001042).

\section{Список використаних джерел:}

1. Rasali, D. P., Shrestha, J. N. B., \& Crow, G. H. (2006). Development of composite sheep breeds in the world: A review. Canadian Journal of Animal Science, 86(1), 1-24. https://doi.org/10.4141/A05-073

2. Kijas, J. W., Lenstra, J. A., Hayes, B., Boitard, S., Neto, L. R. P., San Cristobal, M., ... \& Paiva, S. (2012). Genome-wide analysis of the world's sheep breeds reveals high levels of historic mixture and strong recent selection. PLoS Biol, 10(2), e1001258. https://doi.org/10.1371/journal.pbio.1001258

3. Assan, N., 2020. Effect of genetic and non-genetic factors on growth traits in goats and sheep production. Scientific Journal of Zoology, 9(1), 106-122.

4. Assan, N., \& Makuza, S. M. (2005). The effect of non-genetic factors on birth weight and weaning weight in three sheep breeds of Zimbabwe. Asian-australasian journal of animal sciences, 18(2), 151-157. https://doi.org/10.5713/ajas.2005.151

5. Eskandarinasab, M., Ghafouri-Kesbi, F., \& Abbasi, M. A. (2010). Different models for evaluation of growth traits and Kleiber ratio in an experimental flock of Iranian fat-tailed Afshari sheep. Journal of Animal Breeding and Genetics, 127(1), 26-33. https://doi.org/10.1111/j.1439-0388.2008.00789.x

6. Vesely, J. A., \& Peters, H. F. (1964). The effects of breed and certain environmental factors on birth and weaning traits of range sheep. Canadian Journal of Animal Science, 44(2), 215-219. https://doi.org/10.4141/cjas64-033

7. Saghi, D. A., Khadivi, H., Navidzadeh, M., \& Nikbakhti, M. (2007). Study on influence of environmental effect on birth weight, weaning weight and daily growth of Baluchi sheep. Pakistan Journal of Nutrition, 6(5), 436-437. https://doi.org/10.3923/pjn.2007.436.437

8. Sidwell, G. M., \& Miller, L. R. (1971). Production in some pure breeds of sheep and their crosses. II. Birth weights and weaning weights of lambs. Journal of Animal Science, 32(6), 1090-1094. https://doi.org/10.2527/jas1971.3261090x

9. Eltawil, E. A., Hazel, L. N., Sidwell, G. M., \& Terrill, C. E. (1970). Evaluation of environmental factors affecting birth, weaning and yearling traits in Navajo sheep. Journal of Animal Science, 31(5), 823-827. https://doi.org/10.2527/jas1970.315823x

10. Lavvaf, A., \& Noshary, A. (2008). Estimation of genetic parameters and environmental factors on early growth traits for Lori breed sheep using single trait animal model. Pakistan Journal of Biological Sciences, 11(1), 74-79. https://doi.org/10.3923/pjbs.2008.74.79

11. Teklebrhan, T., Urge, M., Mekasha, Y., \& Baissa, M. (2014). Pre-weaning growth performance of crossbred lambs (Dorper $\times$ indigenous sheep breeds) under semi-intensive management in eastern Ethiopia. Tropical Animal Health and Production, 46(2), 455-460. https://doi.org/10.1007/s11250-013-0513-1

12. Sánchez-Dávila, F., Bernal-Barragán, H., Padilla-Rivas, G., del Bosque-González, A. S., Vázquez-Armijo, J. F., \& Ledezma-Torres, R. A. (2015). Environmental factors and ram influence litter size, birth, and weaning weight in Saint Croix hair sheep under semi-arid conditions in Mexico. Tropical Animal Health and Production, 47(5), 825-831. https://doi.org/10.1007/s11250-015-0795-6

13. Mallick, P. K., Pourouchottamane, R., Rajapandi, S., Thirumaran, S. M. K., Venkataraman, R., Nagarajan, G., ... \& Rajendiran, A. S. (2017). Influence of genetic and non genetic factors on growth traits of Bharat Merino sheep in sub-temperate climate of Kodai hills of Tamil Nadu, India. Indian Journal of Animal Research, 51(2), 365-370. https://doi.org/10.18805/ijar.10979

14. Pokhyl, V. I., \& Mykolaychuk, L. P. (2019). Age-related variability of the woollen coat of Romanivska sheep breed. Theoretical and Applied Veterinary Medicine, 7(3), 172-176. (In Ukrainian). https://doi.org/10.32819/2019.71031

15. Vdovychenko, Yu., \& Zharuk, P. (2019). Genetic resources of sheep in Ukraine. Bulletin of Agricultural Science, 97(5), 38-44. (In Ukrainian). https://doi.org/10.31073/agrovisnyk201905-04

16. Voitenko, S. L., Porkhun, M. G., Sydorenko, O. V., \& Inytska, T. Y. (2019). Genetic resources of agricultural animals of Ukraine at the beginning of the third millennium. Animal Breeding and Genetics, 58, 110-119. (In Ukrainian). https://doi.org/10.31073/abg.58.15

17. Petrović, M. P., Caro Petrović, V., Ružić-Muslić, D., Maksimović, N., Petrović, M. M., llić, Z. Z., \& Stojković, J. (2015). Effect of genetic and environmental factors on the phenotype characteristics of lambs. Biotechnology in Animal Husbandry, 31(2), 223233. https://doi.org/10.2298/BAH1502223P

18. Kramarenko, A. S., Kramarenko, S. S., Lugovoy, S. I., \& Yulevich, O. I. (2020). Analysis of the influence of genetic and non-genetic factors on the birth weight and weaning weight of lambs. Scientific Messenger of LNU of Veterinary Medicine and Biotechnologies. Series: Agricultural sciences, 22(93), 14-21. https://doi.org/10.32718/nvlvet-a9303

19. Ryan, B.F., Joiner, B.L., \& Cryer, J.D. (2012). MINITAB Handbook: Update for release 16. - Pacific Grove, CA, USA: Brooks/Cole Publishing Co., $560 \mathrm{p}$.

20. Hight, G. K., \& Jury, K. E. (1970). Hill country sheep production: II. Lamb mortality and birth weights in Romney and Border Leicester $\times$ Romney flocks. New Zealand Journal of Agricultural Research, 13(4), 735-752. https://doi.org/10.1080/00288233.1970.10430507 
21. Benyi, K., Norris, D., Karbo, N., \& Kgomo, K. A. (2006). Effects of genetic and environmental factors on pre-weaning and postweaning growth in West African crossbred sheep. Tropical Animal Health and Production, 38(7-8), 547-554. https://doi.org/10.1007/s11250-006-4416-2

22. Morris, C. A., Hickey, S. M., \& Clarke, J. N. (2000). Genetic and environmental factors affecting lamb survival at birth and through to weaning. New Zealand Journal of Agricultural Research, 43(4), 515-524. https://doi.org/10.1080/00288233.2000.9513448

23. Gama, L. T., Dickerson, G. E., Young, L. D., \& Leymaster, K. A. (1991). Effects of breed, heterosis, age of dam, litter size, and birth weight on lamb mortality. Journal of Animal Science, 69(7), 2727-2743. https://doi.org/10.2527/1991.6972727x

24. Vesely, J. A., \& Slen, S. B. (1961). Heritabilities of weaning weight, yearling weight, and clean fleece weight in range Romnelet sheep. Canadian Journal of Animal Science, 41(1), 109-114. https://doi.org/10.4141/cjas61-014

25. Hazel, L. N., \& Terrill, C. E. (1945). Effects of some environmental factors on weanling traits of range Rambouillet lambs. Journal of Animal Science, 4(4), 331-341. https://doi.org/10.2527/jas1945.44331x

26. Hazel, L. N., \& Terrill, C. E. (1946). Effects of some environmental factors on weanling traits of range Columbia, Corriedale and Targhee lambs. Journal of Animal Science, 5(3), 318-325. https://doi.org/10.2527/jas1946.53318x

27. Ploumi, K., \& Emmanouilidis, P. (1999). Lamb and milk production traits of Serrai sheep in Greece. Small Ruminant Research, 33(3), 289-292. https://doi.org/10.1016/S0921-4488(99)00027-9

28. Bathaei, S. S., \& Leroy, P. L. (1994). Lamb growth performance and factors affecting body weight of Iranian fat-tailed Mehraban breed of sheep. Revue d'Elevage et de Medecine Veterinaire des pays Tropicaux, 47(1), $113-116$. https://doi.org/10.19182/remvt.9122

29. Yilmaz, O. S. M. A. N., Denk, H., \& Bayram, D. A. V. U. T. (2007). Effects of lambing season, sex and birth type on growth performance in Norduz lambs. Small Ruminant Research, 68(3), 336-339.https://doi.org/10.1016/j.smallrumres.2005.11.013

30. Selaive-Villarroel, A. B., Maciel, M. B., \& Oliveira, N. M. D. (2008). Effects of weaning age and weight on lamb growth rate of Morada Nova breed raised in a tropical extensive production system. Ciência Rural, 38(3), $784-788$. https://doi.org/10.1590/S0103-84782008000300030

31. Alsheikh, S. (2005). Effect of inbreeding on birth and weaning weights and lamb mortality in a flock of Egyptian Barki sheep. ISAH-Warsaw: Poland, 1, 187-191.

\section{С. С. Крамаренко, О. С. Крамаренко, С. І. Луговий, Д. Балан, К. В. Земоглядчук. Вплив породи, плідника та середовищних факторів на живу масу ягнят при народженні та відлученні}

Головною метою дослідження є аналіз певних факторів, що впливають на мінливість живої маси ягнят при народженні та відлученні. В аналіз було включено дані щодо 2603 вівцематок, від яких було отримано 3961 ягнят протягом п'яти років дослідження. Аналіз даних було проведено на підставі алгоритму дисперсійного аналізу із використанням процедури Загальної Лінійної Моделі (GLM) в статистичній програмі Minitab Release 13.1. Отримані результати свідчать про наявність вірогідного впливу року ягніння, породи, генотипу барана-плідника, віку вівщематок, розміру гнізда (типу народження) та статі ягнят на їх живу масу при народженні та відлученні.

Ключові слова: жива маса ягнят при народженні та відлученні; генотип барана-плідника; рік ягніння; вік вівцематки; розмір гнізда (тип народження); стать ягнят; асканійська тонкорунна порода.

\section{С. С. Крамаренко, А. С. Крамаренко, С. И. Луговой, Д. Балан, К. В. Земоглядчук. Влияние породы, производителей и факторов среды на живую массу ягнят при рождении и отъеме}

Главная цель исследования - анализ определенных факторов, влияющих на изменчивость живой массы ягнят при рождении и отъеме. В анализ включены данные о 2603 овцематках, от которых получено 3961 ягнёнок в течение пяти лет исследования. Анализ данных был проведен на основании алгоритма дисперсионного анализа с использованием процедуры Всеобщей Линейной Модели (GLM) в статистической программе Minitab Release 13.1. Полученные результаты свидетельствуют о наличии возможного влияния года окота, породы, генотипа барана-производителя, возраста овцематок, размера гнезда (типа рождения) и пола ягнят на их живую массу при рождении и отъеме.

Ключевые слова: живая масса ягнят при рождении и отъеме; генотип барана-производителя; год окота; возраст овцематки; размер гнезда (тип рождения), пол ягнят; асканийская тонкорунная порода. 